\title{
THE END OF ART AND PATOČKA'S PHILOSOPHY OF ART
}

\section{JAN JOSL}

MA, postgradual student, Department of Aesthetics, Faculty of Arts, Charles University in Prague, 11642 Prague, Czech Republic.

E-mail: honzajosl@gmail.com

In this essay I consider the end-of-art thesis in its metaphysical and empirical versions. I show that both use the correspondence theory of truth as the basis for their conception of the history of art. As a counterpart to these theories I have chosen Patočka's conception of the history of art. His theory is based also on the relationship between art and truth, but he conceives truth in the phenomenological sense of manifestation. In the rest of the essay I seek to show the consequences Patočka's conception has for the history of art. In the first part, I set out to show Patocka's critique of Hegel's aesthetics as a system based on the correspondence theory of truth. In particular, I endeavour to explain his critique of some intrinsic problems of Hegel's aesthetics, the general failure of Hegel's system to achieve its goal, and, lastly, Hegel's giving up on the meaning of the art in the present. I also seek to show that Danto's version runs into the same problems and conclusions as Hegel's. In the second part I discuss Patočka's analysis of modern art and the aesthetic attitude, where he finds a hidden affinity between art and aletheia, which Hegel overlooked. The last part of the essay focuses on the consequences that the conception of the truth of art as aletheia have for the history of art. I conclude that art in such a conception represents an independent field of the manifestation of being in history beside philosophy. Moreover, modern and contemporary art do not mean the end of art; rather, they have their place in art history based on aletheia, since they are more focused on the manifestation itself than on what is manifested. Unlike Hegel and Danto, therefore, Patočka retains the historical meaning of modern and contemporary art. His conception of the history of art, summed up under the idea of aletheia, has greater explanatory potential than Hegel's and Danto's conceptions, and it retains the historical meaning of modern and contemporary art.

Key words: Phenomenology, aesthetics, Jan Patočka, truth, Hegel, Danto, history of art.

(C) JAN JOSL, 2016 


\section{КОНЕЦ ИСКУССТВА И ФИЛОСОФИЯ ИСКУССТВА ПАТОЧКИ}

\section{ЯН ЙОСЛЬ}

Магистр философии, постдокторант кафедры эстетики, факультета искусств Карлова Университета в Праге, 11642 Прага, Чешская республика.

E-mail: Honzajosl@gmail.com

Автор рассматривает тезис о конце искусства в его метафизическом и эмпирическом вариантах. В основе концепции искусства, связанной с обоими вариантами, лежит корреспондентная теория истины. В противовес этим тезисам автор рассматривает концепцию истории искусства Паточки. Его теория также основывается на отношении между искусством и истиной, однако истину он понимает в феноменологическом смысле явленности. Затем автор пытается показать следствия концепции Паточки с точки зрения истории искусства. В первой части автор рассматривает критику Паточки гегелевской эстетики как системы, основанной на корреспондентной теории истины. В частности, автор проясняет критику некоторых внутренних апорий эстетики Гегеля, а также неудачу всей системы Гегеля, в особенности в отношении смысла искусства. Приводятся аргументы, согласно которым философия Артура Данто сталкивается с теми же проблемами, что и система Гегеля. Во второй части обсуждается анализ Паточки современного искусства и эстетической установки, а также обнаруженная им скрытая взаимосвязь между искусством и алетейей, не замеченная Гегелем. Последняя часть статьи выявляет следствия алетической концепции истины искусства для истории искусства. При такой концепции истины искусство представляет собой независимое поле явленности бытия в истории, наряду с философией. Более того, современное искусство не означает конца искусства; скорее, оно занимает присущее ему место в истории искусства, основываясь на алетейе - ведь это искусство сосредотачивается, скорее, на самой явленности, чем на том, что именно является. Таким образом, в отличие от Гегеля и Данто, Паточка сохраняет исторический смысл современного искусства. Его концепция истории искусства, основанная на алетейе, обладает большим объяснительным потенциалом, нежели концепции Гегеля и Данто.

Ключевые слова: Феноменология, эстетика, Ян Паточка, истина, Гегель, Данто, история искусства.

The end-of-art thesis has two versions, one metaphysical, represented by Hegel, and one empirical, represented by Danto. Whereas for Hegel (1975) art has ended because of its inherent inability to represent the absolute, Danto (1984) simply states that the history of art is now a discontinuous «history of discontinuities» (Danto, 1984, 108) and that art died the moment technological development achieved the level of being a perfect copy of reality, which can easily be made by anyone who can use a digital camera.

In this essay, I seek to demonstrate, with the help of Jan Patočka's writings from 
the 1960s, ${ }^{1}$ that it is the history of art based on the conception of truth as adequatio which in both cases leads to such conclusions. Secondly, I seek to show that Patočka argues that this conception of truth is inadequate for art and that the history of art should be understood from the standpoint not of the correspondence theory of truth, but of the phenomenological conception of truth (aletheia) taken in the broad sense of manifestation.

In the first part, I follow Patočka's critique of Hegel's aesthetics as a system based on the correspondence theory of truth, in particular, his critique of some intrinsic problems of Hegel's aesthetics, the general failure of Hegel's system to achieve its goal, and, lastly, Hegel's giving up on the meaning of art in the present. In the second part, I undertake to demonstrate that Patočka finds an affinity not only between modern art and aletheia, but also between aletheia and the aesthetic attitude. In the last part of the essay I focus on some conclusions that follow from Patockka's conception of the history of art and the role of art in the present.

During the second half of the 1960s, Hegel's aesthetic theory appears in Patočka on two levels. The first level is Patočka's work; he was translating Hegel's Aesthetics into Czech at this time. The second is the philosophical level; Patočka was not only translating Hegel, but was also in a philosophical dialogue with him. Consequently, Patočka produced a number of essays on art from 1965 to 1966, dealing in one way or another with Hegel's aesthetic theory. In particular, I have in mind «Hegel's Aesthetic

\footnotetext{
1 Until recently, only a small number of works were concerned exclusively with Patočka's philosophy of art. Naturally, one can reasonably take several different approaches to the topic. The first is mentioned by the editors of Umèní a čas, vols I and II (Chavtík, \& Vojtěch, 2004), who suggest that Patočkas's remarks on art do not come from the heart of his philosophy: «The essays in these two volumes were written on different occasions, often as only a momentary response to a challenge arising from somewhere other than the core of Patočka's own thinking.» (Chvatík, \& Vojtěch, 2004, 369) On the other hand, many thinkers see Patočka's philosophy of art as connected to one of his main philosophical ideas, like the natural world (Zuska, 2002), (Chvatík, 1990), or in connection to the theory of the three movements of life (Šrubař, 1987), or they see art as a reflection on of humankind's place in a history (Biemel, 1987). Recently were finally published two monographies (Ševčík, 2014) and (Blahutková, \& Ševčík, 2014) that are dealing only with Patočka's philosophy of art. Authors of these two monographies, that should be read together, see Patočka's philosophy of art as a place of manifestation of sense. This approach, by its accent on manifestation, is quite close to my own.
} 
Development», «Hegel's Conception of Art as a Thing of the Past», «Hegel's Philosophical and Aesthetic Development», and «Art and Time». In these works, Patočka presents Hegel's late aesthetic theory as motivated by the question «to what extent is it in the power of truth, existing in the form of beauty, to make human beings fundamentally free» (Patočka 2004b, 217). The truth, which is supposed to free human beings, is, in Patočka's view, conceived by Hegel as correspondence. «The main axis in this hierarchy consists in the idea of adequacy. Hegel starts from the traditional idea of adequatio intellectus ad rei, and states its possible variations.» (Patočka, 2004a, 275-276)

Using the traditional conception of truth as adequatio intellectus et rei, Hegel formulates its three essential variations: speculative, that is, adequatio rei ad intellectum creantem; aesthetic, that is, adequatio intellectus finite ad infinitum; and logical in the sense of a proposition, adequatio intellectus finite ad rem creatam. ${ }^{2}$

Hegel's idea of understanding art as an organ of beauty by its relation to the truth is in Patočka's view a good point of departure. Since this attitude gives us a measure by which to define what art is and is not, what great art is and is not, and provide us with knowledge of how the artistic universe is organized, it also allows us to avoid a decline to arbitrariness of measures, programmes, and subjectivism (Patočka, 2004b, 223). Even though in Patočka's view Hegel is right to consider the truth to be the essence of art, «he searches for the truth in the wrong place» (Patočka, 2004a, 302). One reason for Hegel's misconception, according to Patočka, is that Hegel was seduced by the temptation to understand the very basis of our experience as the absolute subject, as God, and this is why, again according to Patočka, Hegel adopts the theologically motivated correspondence theory of truth (Patočka 2004a, 294).

A consequence of Hegel's approach, Patočka argues, is that the plurality of modern art «no longer expresses any general interest in which people could be united; instead, art has become a matter of subjective likes and interests [...], its truth is secondary, and the liberation that art offers is incomplete.» (Patočka 2004b, 223)

Patočka follows Hegel's initial idea about the relationship of art to truth. He is

\footnotetext{
2 The very same division is mentioned in (Patočka, 2004b, 219-220). K vývoji Hegelových estetických názorů (On the development of Hegel’s aesthetic views), or repeated in (Patočka, 2004e, 323-324), «Učení o minulém rázu umění» («Hegel's Conception of Art as a Thing of the Past»).
} 
convinced, however, that a different conception of truth would be more appropriate for art. First of all, Patočka points out some shortcomings of the use of correspondence theory in Hegel's aesthetics. In symbolic art, Hegel (Hegel, 1975a, 303-426), captivated by his own conception of truth as adequatio, overlooks, according to Patočka, a whole period of art that lay beyond Europe. Non-European art is not, despite what Hegel thinks, an imperfect art. On the contrary, the frame of the correspondence theory of truth, which is implicit in Hegel, is simply not, according to Patočka, capable of dealing with the variety of artistic styles:

\begin{abstract}
Symbolic art, however, contains the whole of the ancient Orient, Persia, India, Mesopotamia, and, primarily, Egypt, Jewish, and Islamic verse, and so forth; Hegel does not mention East Asian art at all, but it should be mentioned here. This means that the biggest part of artistic development, in fact all art outside Europe, has escaped Hegel's conception. (Patočka, 2004a, 299)
\end{abstract}

I believe that this does not hold for Hegel. Though Danto's theory rests not on any metaphysical principle like God or the Absolute, but on the idea of the perfect copy, it is clear that at heart it relies on the same principle as Hegel's system, that is, that the truth of art rests in correspondence. Danto not only explicitly refers to Hegel as the source of his theory, but he also runs into the very same problems as Hegel. Using the idea of the perfect copy as the truth of art, Danto is forced to consider Chinese and Japanese art to have been «retarded by technological slowness» (Danto, 1984, 91), instead of accepting its difference.

Not only is the correspondence theory unable to handle a variety of artistic styles, it is also unable to handle a variety of types of art. Patočka finds an example of this in Hegel's conception of architecture (Hegel, 1975b, 630-700):

It is most perfectly evident in architecture, which he [Hegel] has completely dissociated from the applied arts and by the term of the spiritual, put together with the depictive and expressive arts of sculpture, painting, and music. True, he succeeded in achieving some deep insights into the common origin of sculpture and architecture as well as into the late origin of purposefully artistic architecture; yet the notion that art should depict or express the Absolute fails most evidently here. (Patočka, 2004a, 301)

Amongst types of art, architecture thus represents for Hegel the imperfection of identity of form and meaning, which symbolic art represents for him in the area of artistic styles. Hegel is, Patočka's argues, blind to the fact that works of architecture 
serve rather as something like orientation points in our world, representing the way we understand and live in space. Patočka gives an example of this in «An Essay on Read's Book on Sculpture» (Patočka, 2004 ff., 441-453). Here, he describes how a prehistorical monolith introduces into reality the dimensions of close and far, home and foreign, and thus represents the origin of architecture and our understanding of space. And Danto again encounters the same problems as Hegel. If the history of art is taken as progress in the accuracy of duplication, then we are forced to deny the history, for example, of literature or music. Starting from Patočka's critique of Hegel, we now see that a theory of the history of art based on the correspondence theory of truth will probably have significant difficulties in grasping the phenomena of art in the fullness of its historical styles and types. A pattern of searching, reaching, and overcoming an ideal inherent to the end-of-art thesis, either in its metaphysical form (Hegel) or in its empirical form (Danto), is in fact the very thing that flattens our view of art.

In his writings from the 1960s, Patočka strives to overcome these shortcomings of the history of art which are based on the correspondence theory of truth, and finds in art its relation to the phenomenological conception of truth conceived as aletheia. ${ }^{3}$ In «Art and Time», Patočka notes that, with respect to the modern art of Cézanne, Kandinsky, and Mondrian, metaphysical meaning ceases to have any importance. Modern art has given up on any positive meaning or idea. It has also given up on presenting anything specific (Patočka, 2015, 104). In this characterization of modern art, Patočka is in agreement with Hegel and also with Danto, for whom modern art «will bring into existence works which lack historical importance or meaning» (Danto, 1984, 111). But Patočka disagrees with the conclusions. The lack of meaning does not, he argues, suggest that the history of art has ended. Rather, it suggests, according to him, that modern art draws our attention away from what is manifested and turns it instead to the manifestation itself. Modern art is, in Patočka's view, «art that wants to be as close

\footnotetext{
3 The fact that Patočka discovers in Hegel a notion of the truth of art that is close to Heidegger's and is distinct from «correctness» is mentioned also in (Major, 1967; Legros, 1992; Ševčík, 2015).
} 
as possible to the source of meaning when it is born in our senses» (Patočka, 2004e, 344). In modern art, he writes, «it is no longer a work of art whose intention is somehow to say, to communicate, what controls its inner world - rather, the world then crystallizes into a world of meaning, which exists only in the work of art and by its grace.» (Patočka, 2015, 105)

Another example of relationship between modern art and manifestation can be found in Patočka's «Some Remarks on Polyperspectivity in Picasso by Walter Biemel» (Patočka, 2004c, 30-34). According to Patočka, polyperspectivity in Picasso's work originates not, as Biemel suggests, in the technological spirit of the period, but in the artist's efforts to go directly to the elements that make painting and its manifestation possible in the first place. To sum up, Patočka, contrary to Hegel, does not disapprove of modern and post-Romantic art, and he discovers its genuine relationship with manifestation, that is, aletheia.

But Patočka does not see the relationship between art and aletheia as residing only in modern art. He also sees it at the very heart of the aesthetic experience. In his essay «Hegel's Conception of Art as a Thing of the Past», Patočka discovers aletheia in Hegel's own conception of the aesthetic attitude. When summarizing Hegel's notion of the aesthetic attitude, he starts with the difference between the aesthetic attitude and the theoretical and practical attitudes. The difference between them, he notes, is reflected in our attitudes towards the world. Whereas theoretical and practical attitudes have their roots in the limited dimension of things in the world, with the aesthetic attitude we do not deal with singular things, with different purposes, with usefulness and effectiveness; instead, we and the thing are free from these worldly relations. With the aesthetic attitude we are therefore dealing with the global aspect of things. It is the world as a whole that appeals to us in aesthetic experience (Patočka, 2004a, 290).

Just how close or distant to Husserl and the classic formulation of the aesthetic attitude is this phenomenological shift to the manifestation itself, liberation from worldly relations, as described by Patočka? Patočka briefly describes the effect that art has on the viewer as a «fantastic reflection» (Patočka, 2006, 288). This «fantastic reflection», however, must be understood differently from Husserl's conception of reflection in fantasy.

Patočka has several objections to Husserl's conception of reflection. The first has to do with the reach of reflection. In both the postscript to the Czech edition of Cartesian 
Meditations and in «The Natural World Reconsidered Thirty-three Years Later», Patočka argues similarly against Husserl. According to Patočka, reflection does not go beyond the evidence of self-existence. Consequently, reflection includes nothing about the structure or content of our existence (Patočka, 1968, 183; and Patočka, 2009, 267). He sees the second problem in the nature of reflection, and questions the idea that reflection is theoretical in nature:

In its true nature does reflection really mean reshaping the bond that binds me to my existence? Is it really, because of that, an approach to a completely different Self, to the absolute transcendental subject, to the stream of experience that constitutes the whole of objectivity? Is the stream of experience, where every experience has its type, its essence and even its essential relation to other experiences, really the essence of my being? Is such a conception not a profound misunderstanding of one's own self, of one's own being? (Patočka, 2009, 268)

Rather, argues Patočka, reflection has practical purpose. Reflection does not mean to step out of the world as is suggested, in Patočka's view, by Husserl. The true purpose of reflection is to serve as an opposite movement to the movement of falling into the world in Heideggerian terms. The purpose of reflection thus represents Patočka's third objection to Husserl's conception of reflection (Patočka, 2009, 269).

The last point of Patočka's discussion with Husserl concerns the possibility of reflection:

We either understand the concept of reflection as absolute self-evidence, but then reflection is truly going to be a leap into a kind of being radically different from the being of prereflexive life, or we have to rob reflection of its access to absolute immanence, to being that is not given in anticipations (in perspectives). (Patočka, 2009, 270-271)

Such reflection gives us being and world in their various perspectives, but provides no knowledge of absolute world structures. The history of art, for Patočka, thus expresses a different understanding of the world and of being in time:

The world of our life (Lebenswelt) is the world of this special life; in different lives and worlds there are of course some common features, but they are woven together in special ways connected with this concrete life, its destiny, and its dénouement. (Patočka, 2006, 291)

This is why, according to Patočka, a work of literature, and in fact any work of art, is a «conjuring up of the world in its special essence» (Patočka, 2006, 290). Patočka's 
«fantastic reflection» should therefore be understood in the light of these objections, which moves his position considerably closer to Heidegger's. To sum up, we may say that Patočka's aesthetic attitude is based on practical reflection that makes us disinterested in the worldly relation in terms of everydayness and inauthenticity in order to open up the world and being in their historical, yet total aspect:

The viewer who considering how one's approach to life and things is created is not completely disinterested; rather, he is fighting against the dilution of his interest in his own being into individual factual interests, interested in disinterestedness, in truth - and in this will to freedom from being thrall to his own factual self and its interests he is nevertheless a worldly spectator, even if not explicitly positing the world. (Patočka 2009, 270)

But what makes this kind of attitude possible? Patočka points out that it is not in fact anything. Rather, it is nothing, the power of negativity, death, and the past that are at the core of the aesthetic attitude. Heidegger argues that these are capable of freeing us from our worldly interests. Aesthetic experience is for Patočka, then, close to the anxiety that reveals the world as a whole in Heideggerian terms, but with a slight difference:

Beauty is not the terrifying. It is, as Rilke said, only its beginning, the gaze of the eternal back on earth, as Klee said; it is the Indian Bacchus that veils himself in sensation and the image, under which, according to Hegel, lurks the terrifying. The negativity of nothingness manifests itself not in this its pure form, but in its positivity, in its overcoming the finitude of the present moment. (Patočka, 2004e, 344)

It is thanks to this negativity hidden in art that in the aesthetic attitude we and the work of art are liberated from worldly relations. The free nature of the aesthetic attitude is, in Patočka's view, similar to the freedom that we can find in a game. But, compared to a game, the game of the aesthetic attitude is free from the world not merely in some aspects, but absolutely. Patočka therefore concludes: «Art is an absolute game, that is, a game that does not presuppose any previous a priori existence; rather, it is the game of this existence itself.» (Patočka, 2004e, 343)

Whereas in the ludic character of modern art Hegel and Danto see evidence that it no longer has a historical meaning and that art has actually lost the freedom to entertain and other purposes, Patočka argues the opposite. Originating in the phenomenological position, the ludic character of the aesthetic attitude is, for him, a field in which the subject and the work of art can manifest themselves for themselves 
because they are free from any external ideas or measures. Consequently, at the heart of the aesthetic attitude lies hidden, for Patočka, the inherent relationship between art and manifestation itself.

\section{III}

These are the reasons why Patockka believes that the truth of art rests in aletheia rather than in the correspondence to either the metaphysical or the empirical ideal. But what are the consequences of this for the history of art?

Ever since Plato, art has often been discredited by the correspondence idea of truth. In Book Ten of the Republic, Plato criticizes art conceived as mimesis mimeseos that represents the lowest level of truth and is even considered to be dangerous. ${ }^{4}$ For Hegel, art is also the lowest possible form of truth. The position of art in these theories is always dependent on the broader philosophical context, that is, what is considered to be true being. Art is then condemned on the basis of its correspondence to it.

If aletheia is the truth of the art, then art creates an independent field of manifestation that has no need of any other external source to fill it with meaning. Art as aletheia contains its meaning in itself. It is fair to say that Patočka's conception of art as aletheia thus offers a way to free the history of art from the sway of correspondence theory. If this is so, then modern art in no way represents the end of art, contrary to what Hegel and Danto suggest. The lack of reference to such meaning, either in its metaphysical version (true being) or in its empirical version (perfect copy), therefore does not imply that art is finished. In fact, modern art, having given up on presenting anything concrete, is, for Patočka, the most sincere art so far, because it draws our attention away from what is manifested and turns it to manifestation itself. Modern art thus returns to the source of aletheia, that is, in "[Wolfgang] Weischedel's terms, problematicity; in Heidegger's terms, the concealment of what-is as a whole as the foundation of all openness and all uncovering. Thus, it is this mystery that expresses itself in the shaking of naively accepted

\footnotetext{
4 See Heidegger's interpretation of Plato's doctrine of truth (Heidegger, 1998, 155-182). Heidegger demonstrates that Plato eventually subscribes to truth conceived as correctness of view. It is from this conception that Plato criticizes art in Book Ten of the Republic.
} 
meaning.» (Patočka, 1996, 77)

Since, for Patočka, the historical character of art comes from aletheia as the process of manifestation, the course of the history of art reflects humankind's relationship to the source of manifestation, its epiphany to us, and our effort to understand it and name it, rather than our searching and reaching for some ideal.

It is true that in «Art and Time» Patočka suggests that the history of art may be divided into two great periods; one he calls «artistic», the other «aesthetic». A work of art is truly either a gate to metaphysical reality, in which case modern art represents a decline, or it is an autonomous sign and any metaphysical qualification of art is an illusion. But as Miloš Ševčík has clearly argued, in the context of Patočka’s later works, «the meaning of earlier art can reasonably be seen as a supposedly definitive meaning, religious in nature, which disguises the disclosed problematic nature of meaning. The meaning of modern art, on the other hand, can be seen as meaning that is problematic but stems from an explicit relation to being.» (Ševčík, 2015, 96)

Without going into the details of the development of these divisions in Patočka's philosophy, I wish to point out that such an outline of the history of art would have been impossible if Patočka had not approached the history of art from the phenomenological standpoint of manifestation. True, he himself had serious doubts about works of contemporary art. He describes post-1945 art as cybernetic, industrial, energetic, nanotechnical, and even non-European. ${ }^{5}$ Nevertheless, Patočka is more tolerant of our technical age than Husserl or Heidegger. In Heretical Essays in the Philosophy of History, he argues that technological civilization is not completely decadent, and gives two reasons towards explaining why this is so. The first is that the decadent character of technological civilization is not entirely its own fault; rather, it is partly an inherited problem. The second, and most important, reason is that the technological age contains within itself

\footnotetext{
${ }^{5}$ In 1969, Patočka visited an exhibition of post-1945 American painting, where he had an opportunity to see, for example, works by Andy Warhol, Roy Lichtenstein, and Lowell Nesbitt. Patočka summarizes his impressions as follows: «If we go to an exhibition of contemporary American painting, we will from the very beginning encounter an absolutely different atmosphere from the one that has hitherto been considered «modern' post-Cubist art. The deformation and transformation of form, as well as the search for the laws of structure, the world of dreams and forms, have all almost entirely vanished. There is no more making the invisible visible in the spiritual sense; all we see is the forces of industrial production of our nanotechnical age that presents to our eyes the artefacts they produce.» (Patočka, 1999, 87-88)
} 
the possibility of a «turn from accidental rule to the rule of those who understand what history is about» (Patočka, 1996, 118), that is, history as the shaken certitude of pre-given meaning. And we may therefore suppose that in Patockka's position there is no reason why the technical age cannot have its own artistic expression: «We do not see why the prosaic and hypertechnical age - in spite of all the suffering and excess that it causes to man beyond the usual biologically human measure - cannot find aesthetic liberation and manifestation of being commensurate to itself.» (Patočka, 2004e, 347)

Thomas Mann's Doctor Faustus (1947) is for Patočka an example of such an artwork. According to Patočka, the main topic of this novel is «to create a work of art at a miserable time, when all resources and possibilities seem to be exhausted» (Patočka, 2004d, 520). The main character, Adrian Leverkühn, is an artist who willingly makes a pact with the Devil, that is, with the evil of the world, in order to create an absolute masterpiece. For Patočka, this means that he does not consider evil to be a power independent of himself, but rather that he does indeed take responsibility for his actions. This responsibility, discovered by a guilty conscience, illustrates the dialectical relationship between art and technological reality. On the one hand, the art of today accepts technological development, and in many cases falls into the trap of the industrialization of culture, the machinery of supply and demand, and the influence of the mass media, and, as Danto and Hegel fear, loses its free character. On the other hand, art represents an area where technological progress is put into the service of human creativity and freedom, and thus gives rise to the feeling that in other areas we are guilty of having let technology control our actions.

Ultimately, even contemporary art can, for Patočka, represent the creative power of «human beings, that is, an ability to allow being to manifest itself» (Patočka, 2015, 112) and therefore even in the technological age art can, for Patočka, be a place of human freedom and aletheia.

It should be clear from the preceding discussion, I hope, that the pattern of searching, reaching, and overcoming an ideal that is inherent to the history of art based on correspondence theory leads to the end-of-art thesis. I have tried here to show too that Patočka considers aletheia to be the truth of art based on his interpretation of modern artworks as well as on his analysis of the aesthetic attitude. Eventually, I suggested that since Patočka considers art under the idea of aletheia, and not under 
correspondence, his approach not only has greater explanatory potential, but also offers a way to keep the historical meaning of art face to face with the end of art and cultural pessimism in the circumstances of today.

\section{REFERENCES}

Biemel, W. (1985). Bemerkungen zu Jan Patočkas Deutung der Kunst. Phanomenologishe Forschungen: Studien zur Philosophie von Jan Patočka, 17, 32-52.

Blahutková, D., \& Ševčík, M. (2014). Patočkovy interpretace literatury [Patočka's Interpretations of Literature]. Červený Kostelec: Pavel Mervart. (in Czech).

Chvatík, I., \& Vojtěch, D. (2004). Ediční komentář [Editorial note]. In J. Patočka, Umění a čas [Art and Time]: Vol. I (367-428). Prague: Oikoymenh. (in Czech).

Chvatík, K. (1990). Filosofie umění Jana Patočky [Jan Patočka’s Philosophy of Art]. Proměny, 27 (4), 28-33. (in Czech).

Danto, A. C. (1984). The End of Art. The Philosophical Disenfranchisement of Art (81116). New York, NY: Columbia University Press.

Hegel, G. F. W. (1975a). Aesthetics: Lectures on Fine Art: Vol. I. Oxford: Oxford University Press.

Hegel, G. F. W. (1975b). Aesthetics: Lectures on Fine Art: Vol. II. Oxford: Oxford University Press

Heidegger, M. (1998). Plato's Doctrine of Truth. In W. McNeill (Ed.), Pathmarks. Cambridge: Cambridge University Press.

Legros, R. (1992). Patočka et Hegel. In M. Richir, \& E. Tassin (Eds.), Jan Patočka: Philosophie, phénomenologie, politique (45-53). Grenoble: Millon.

Major, L. (1967). Sebeuvědomění a čas: K Patočkově interpretaci Hegelovy estetiky [Selfawarness and Time: Notes on Patočka's Interpretations of Hegel's Aesthetics]. Filosofický časopis, 15, 625-635. (in Czech).

Patočka, J. (1968). Husserlova fenomenologická filosofie a "Karteziánské meditace" [Husserl's Phenomenological Philosophy and "Cartesian Meditations"]. In E. Husserl, Karteziánské meditace [Cartesian Meditations] (161-190). Prague: Svoboda. (in Czech).

Patočka, J. (1996). Does History Have a Meaning? In J. Dodd (Ed.), Heretical Essays in 
the Philosophy of History. Chicago, IL: Open Court.

Patočka, J. (1999). Evropa a doba poevropská [Europe and Post-Europe]. In Péče o duši II

[Care for the Soul]. Sebrané spisy [Collected Works]: Vol. II. Prague: Oikoymenh. (in Czech).

Patočka, J. (2004a). Hegelův filosofický a estetický vývoj [Hegel’s Philosophical and Aesthetic Development]. In J. Patočka, Umění a čas [Art and Time]: Vol. I (227302) Prague: Oikoymenh. (in Czech).

Patočka, J. (2004b). K vývoji Hegelových estetických názorů [On the Development of Hegel's Aesthetic Views]. In J. Patočka, Umění a čas [Art and Time]: Vol. I (216226). Prague: Oikoymenh. (in Czech).

Patočka, J. (2004c). Poznámky k polyperspektivě u Picassa [Some Remarks on Polypercpectivity in Picasso]. In J. Patočka, Umění a čas [Art and Time]: Vol. II (30-34). Prague: Oikoymenh. (in Czech).

Patočka, J. (2004d). Smysl mýtu o paktu s dáblem [The Meaning of Myth about Pact with the Devil]. In J. Patočka, Umění a čas [Art and Time]: Vol. I (510-525). Prague: Oikoymenh. (in Czech).

Patočka, J. (2004e). Učení o minulém rázu umění [Hegel's Conception of Art as a Thing of the Past]. In J. Patočka, Umění a čas [Art and Time]: Vol. I (319-347). Prague: Oikoymenh. (in Czech).

Patočka, J. (2004f). Úvahy nad Readovou knihou o sochařství [An Essay on Read's Book on Sculpture]. In J. Patočka, Umění a čas [Art and Time]: Vol. I (441-453). Prague: Oikoymenh. (in Czech).

Patočka, J. (2006). Spisovatel a jeho věc [Writer and his Thing]. In Češi [Czechs]: Vol I (280-292). Prague: Oikoymenh. (in Czech).

Patočka, J. (2009). “Přirozený svět” v meditaci svého autora po třiatřiceti letech [“The Natural World" Reconsidered thirty-three Years Later]. In Fenomenologické spisy II (265-334). Prague: Oikoymenh. (in Czech).

Patočka, J. (2015). Art and Time. Estetika: The Central European Journal of Aesthetics, 52(1), 99-113.

Ševčík, M. (2014) Umění jako vyjádření smyslu: Filozofie umění Jana Patočky [Art as an Expression of Sense: Jan Patočka’s Philosophy of Art]. Červený Kostelec: Pavel Mervart. (in Czech). 
Ševčík, M. (2015). Patočka's Interpretations of Hegel's Thesis on the Past Character of Art. Estetika: The Central European Journal of Aesthetics, 52(1), 78-113.

Šrubař, I. (1987). Zur Stellung der Kunst in Patočkas Philosophie. In J. Patočka, Kunst und Zeit (31-48). Stuttgart: Klett Cotta.

Zuska, V. (2002). Mimésis - fikce - distance: k estetice XX. století [Mimésis - Fiction - Distance: to the Aesthetics of the XXth Century]. Prague: Triton. 